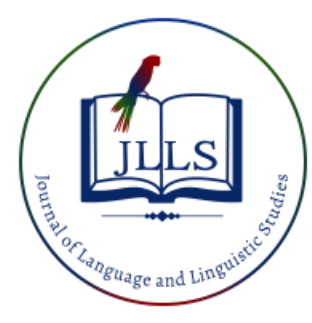

Available online at www.jlls.org

JOURNAL OF LANGUAGE AND LINGUISTIC STUDIES

ISSN: 1305-578X

Journal of Language and Linguistic Studies, 17(3), 1129-1140; 2021

\title{
The reproduction of the gothic motifs of Frankenstein in the COVID-19 journalistic discourse: A corpus-based critical discourse analysis approach
}

\author{
Fahad M. Alliheibi a 1 iD, Abdulfattah Omar ${ }^{\text {b }}$ iD, Nasser Al-Horais c ${ }^{c}$ iD \\ ${ }^{a}$ King Abdulaziz University, Jeddah Saudi Arabia \\ ${ }^{b}$ Prince Sattam Bin Abdulaziz University, Al-Kharj, Saudi Arabia \\ ${ }^{c}$ Qassim University, Buraidah, Saudi Arabia
}

\section{APA Citation:}

Alliheibi, F.M., Omar, A., Horais, N.A. (2021). The reproduction of the gothic motifs of Frankenstein in the COVID-19 journalistic discourse: A corpus-based critical discourse analysis approach. Journal of Language and Linguistic Studies, 17(3), 1129-1140. Doi: $10.52462 /$ jlls. 80

Submission Date: 25/04/2021

Acceptance Date: 25/07/2021

\begin{abstract}
The recent horrors of the COVID-19 pandemic have renewed interest in Gothic fiction in general and Mary Shelley's Frankenstein in particular. The image of Frankenstein has become associated with the COVID-19 discourses (e.g. literary, journalistic, medical, and social media) as reflected in the representation of the horrors of isolation and contagion. The influence of the novel is clearly reflected in literary, medical, scientific, and everyday discourses today. Despite the prolific literature on the representation of Gothic elements and motifs, reflections on Gothic motifs in the reproduction of COVID-19 discourse have not yet been elaborated. In light of this, the paper seeks to explore the manipulation and reproduction of Shelley's Frankenstein in the COVID-19 journalistic discourse. A corpus of 542 editorials and opinion commentaries from 83 newspapers was built. The corpus included only editorials and opinions written in English. Corpus-based critical discourse analysis was used. The results indicate that the Gothic motifs of Frankenstein are manipulated and reproduced in the journalistic discourse of COVID-19 to depict the chaos and destruction caused by the enormously powerful and catastrophic virus/monster that has come to rule the world. The COVID-19 journalistic discourse based on the fictional image of Frankenstein represents a distinct discourse genre that manipulates Gothic motifs in the thematic representations of the horrors associated with the pandemic itself on the one hand, and the social, economic and political problems and crises that have shaken the stability of the entire world on the other. It can be concluded that this representation has been developed and generated from the interaction between the writers and the text of Frankenstein.
\end{abstract}

Keywords: Corpus-based critical discourse analysis; COVID-19; Frankenstein; Gothic motifs; Journalistic discourse

\section{Introduction}

Numerous studies have explored the thematic features of Gothic fiction. Many of these studies have focused on the 19th-century Gothic novel Mary Shelley's Frankenstein (1869), which is

\footnotetext{
${ }^{1}$ Corresponding author.

E-mail address: fallaheebi@kau.edu.sa
} 
distinguished by its supernaturalism, its fascination with social transgression, and its departure, in formal terms, from the emerging norm of novelistic realism (Garrett, 2018). Mary Shelley was born on 30 August 1797 in London, and died on 1 February 1851. Her parents were famous writers, but her mother died only four weeks after her birth. She was cared for by her stepmother. It was at home that Mary developed into a person of letters, following in the family tradition of writers and thinkers (Johnson, Butler, \& Felman, 2014; Sampson, 2019). She was married to the famous Romantic poet, Percy Bysshe Shelley, who died very young. She became a well-known novelist and her Gothic novel, Frankenstein, is a masterpiece that still triggers the curiosity of many readers and grips their attention (Mellor, 1988). The idea of Frankenstein came to Mary while she was competing with other writers in writing a sketch for a horror novel. Her idea was so horrific that Lord Byron ran shrieking in horror on hearing it. Conversations with her husband, Shelley, and her friend, Byron, fuelled her curiosity and induced her to write one of the best Gothic or science fiction novels ever known (Buzwell, 2014).

Over the last 200 years, Frankenstein has infused both scientific and popular discussions. Frankenstein has been linked with different diseases, events and wars. It has even been linked with some people thought to represent a danger to humanity. Recently, for instance, President Donald Trump was represented in some political discussions and reports as the monster Frankenstein, threatening American democracy. With the outbreak of the COVID-19 pandemic and the horrors it has brought to all people around the world, however, Frankenstein has come to be a hot topic in debates in the fields of science, medicine and technology, and the Gothic motifs in Mary Shelley's Frankenstein have been reproduced in literal, psychological, scientific, popular, and journalistic discourses. The issues raised by Mary Shelley, including the dangers of moral transgression and excessive knowledge and the conflict between science on the one hand and religion on the other, are among the most controversial topics today. With its connotations, "Frankenstein" is one of the most frequently used terms in the COVID-19 discourse.

In light of this argument, this article seeks to explore the thematic representations of horrors and motifs in Mary Shelley's Frankenstein and the ways in which these motifs and horrors are manipulated and reproduced in the COVID-19 journalistic discourse. The rationale is that journalistic discourse is not only about news; it involves ideologies and social practices that are associated with the reproduction of events to influence the public and shape public opinion. Baker (2006, p. 72) argues that "journalists are able to influence their readers by producing their own discourses or helping to reshape existing ones. Such discourses are often shaped by citing the opinions of those in powerful and privileged positions". In this regard, journalistic discourse is claimed to have had a widespread effect on shaping public opinion concerning the pandemic events of COVID-19. The rest of the paper is organized as follows. Section 2 provides a brief survey of the representation of the horror themes in Gothic fiction. Section 3 presents the methodology. Section 4 comprises a corpus-based discourse analysis of the selected data. Section 5 discusses the findings and section 6 concludes.

\section{Literature Review}

The Gothic genre is a type of fiction that arouses the passions of fear and horror through employing darkness, desolate and haunting settings, foreboding events, horrible murders, tempestuous weather and destructive storms, supernatural, ghosts and monsters, mystery and suspense, exotic and dreadful characters, adventure narratives, complicated plots, and traumatic experiences to create a strong psychological sense of horror and to help us understand ourselves better (Hogle, 2002; Punter, 2015). The origin of the word "Gothic" can be traced back to the "Goths", a German tribe that ravaged Europe in the third, fourth, and fifth centuries (Peck, 1897; Raškauskienè, 2009). As a pejorative term, it has become a synonym for barbarism and has usually had negative connotations and implications (Punter, 2014). With the publication of the first Gothic novel, The Castle of Otranto, in 1764, 
Raškauskienè (2009) argues that Horace Walpole made the Gothic novel fashionable and the term Gothic came to be applied to literary works, being associated with the attributes "supernatural", "grotesque", and "fantasy". Walpole (1982) explains the reasons for writing the novel, saying:

It was an attempt to blend two kinds of romance, the ancient and the modern. In the former all was imagination and improbability. In the latter, Nature is always intended to be, and sometimes has been, copied with success. Invention has not been wanting, but the great resources of fancy have been dammed up, by a strict adherence to common life. but if, in later species, Nature has cramped imagination, having been totally excluded from old romances. (p. 7)

The literature suggests that different theories have been developed in relation to the critical study and literary criticism of Gothic fiction (Geary, 1992; Mulvey-Roberts, 1998; Wright, 2007). Studies in this tradition used to focus on the literary and aesthetic aspects of texts. The second half of the $20^{\text {th }}$ century, however, witnessed the emergence of a number of linguistic approaches to the analysis of literary texts. This can be dated back to 1958, with Roman Jakobson's presentation "Closing statement: Linguistics and poetics" to the Conference on Style at Indiana University. Jakobson (1960) stressed that linguistics and literature are closely related and went so far as to suggest that literature is best described in terms of linguistics. His argument was that that literature is not in contradistinction to linguistics and the long separation between the two disciplines has been based on an erroneous interpretation of the nature of literature and poetics. The claim is that is the global science of verbal structure makes it possible to analyse literature, which is a verbal structure in the first place. $\mathrm{He}$ explains that there is a close relation between the word and the world; therefore, linguistics can explore all possible problems of relation between literary discourse and the universe of that discourse. Since then, linguistic studies, which had been restricted to the grammar of the sentence, have expanded their focus beyond the sentence to include the grammar of discourse and literary texts (Allan \& Buijs, 2007). The introduction of linguistics to literature has also resulted in the adoption of empirical research methods in literary criticism and critical accounts of different literary genres (Peer, Hakemulder, \& Zyngier, 2012). Such methods, as Louw and Milojkovic (2016) argue, were missing from literary criticism, which had implications for the interpretation of literary texts.

With the emergence of functional linguistics and critical discourse approaches, a connection was made between discourse analysis and Gothic discourses. Critical and functional linguistic approaches have been adopted to explore the representation of Gothic motifs in Gothic fiction. This study, however, is limited to the representation of Gothic fiction in discourse studies. It can be claimed that Gothic fiction has been revived and revitalized at the hands of discourse analysts. The analysis of the Gothic fiction in discourse studies can be traced back to the development of structural linguistics, structural linguists being concerned with the principles of objectivity and scientific truth in the analysis of literary texts. With the development of Michael Foucault's (1990) theory of intertextuality in his book The History of Sexuality, Gothic novels became a rich source for intertextual studies (Edmundson, 2016; Grundmann, 2007; Hermansson, 2001).

In the thematic representation and construction of Gothic motifs and horrors, many discourse studies have focused on exploring the social, political, economic, and cultural aspects of concepts in Gothic fiction (Buckley, 2016; Corstorphine \& Kremmel, 2018; Dunne, 2001; Wisker, 2016). In Reading Gothic Fiction, for instance, Howard (1994) re-analyses Gothic novels through the Bakhtinian approach to discourse analysis. She uses Bakhtin's approach to discourse in her discussion of the discursive strategies in Ann Radcliffe's Mysteries of Udolpho, Matthew Lewis's The Monk, Jane Austen's Northanger Abbey and Mary Shelley's Frankenstein. She claims that discourse analysis approaches can usefully be employed in generating new critical reviews of Gothic novels through exploring the social and political forces and even the feminist aspects in these novels. Similarly, Michelis (2003) provides a new analysis of late $19^{\text {th }}$-century Gothic fiction through exploring the 
representation of sexual identity. She asserts that homosexuality was represented as a taboo combination of sexuality and violence. The analysis of the vampire or Gothic horrors goes beyond this to untrodden areas, such as the social rejection of lesbians and homosexuality and the right of the individual to assert his/her sexual identity. The claim here is that discourse analysis approaches have opened up new venues for the interpretation of Gothic fiction writings that differ from the stereotypical accounts of these writings.

Through corpus linguistics, Gothic fiction has been paired with corpus-based discourse approaches. Corpus linguistics has provided researchers with empirical approaches to explore language use and patterns in Gothic novels and short stories. Despite the potential of corpus approaches for the analysis of Gothic discourse, very little has been done on the issue. The literature also indicates that the reproduction of Gothic motifs in the COVID-19 discourse has not yet been elaborated. This paper seeks to address this gap in the literature through exploring the implications of Gothic motifs in Mary Shelley's Frankenstein for the COVID-19 journalistic discourse.

\section{Methodology}

\subsection{Method}

The study adopts corpus-based critical discourse analysis methods to examine the representation, construction and reproduction of Gothic motifs in Mary Shelley's Frankenstein in journalistic discourse during the COVID-19 pandemic. The rationale is that corpus-based approaches can usefully be employed in conducting a discourse analysis quantitatively and qualitatively through analysing collocations and concordance lines (Salama, 2021).

Corpus linguistics can be defined as "a way of using computers to assist the analysis of language so that regularities among millions of words can be quickly and accurately identified" (Baker \& McEnery, 2015, p. 1). Corpus linguistics is now integrated in discourse models, including conversation analysis, critical discourse analysis, and discourse analysis "as a means for looking at language patterns over much larger datasets" (McCarthy \& O'Keeffe, 2010, p. 3).

In his book, Using Corpora in Discourse Analysis, Baker (2006) argues that corpus-based methods have revolutionized discourse studies, indicating that such studies have hugely benefited from corpus linguistic methods. He adds that the combination of corpus linguistic methods and discourse analysis is useful in that the former supplements the latter. Corpus-based methods have successfully been used to address many of the problems that were associated with discourse studies (Ustabulut \& Keskin, 2020). McEnery and Hardie (2011) explain that corpus-based methods reduce the researcher's subjectivity and bias in terms of data selection and analysis. In other words, corpus-based approaches ensure that the data are sufficiently representative and chosen objectively for the purpose(s) of the research. In other words, corpus-based methods address the problem of the predominance of biased interpretations due to issues of data representativeness, selectivity, partiality, prejudice, and voice. Baker (2006) comments:

By using a corpus, we at least are able to place a number of restrictions on our cognitive biases. It becomes less easy to be selective about a single newspaper article when we are looking at hundreds of articles - hopefully, overall patterns and trends should show through. (p. 12)

Furthermore, corpus-based approaches offer the potential to deal with large bodies of data, unlike traditional approaches, which are usually confined to limited texts. In corpus-based discourse studies, analysts can deal with hundreds and even thousands of texts quickly and accurately through different tools, including frequency, dispersion, and collocation measures (Kennedy, 2014). These tools enable researchers and discourse analysts to look at key topics and linguistic patterns that provide more 
concrete evidence to support their arguments and making generalizations about the data. It is even argued that corpus methods have to be integrated in discourse studies to ensure valid and reliable findings and results (Baker, 2012).

Descriptive findings are generated by searching for particular discourse features in a corpus typically a collection of texts in a specific register, but possibly a single extended text, such as a textbook or a novel - using computational means. Explaining the frequency, significance and use of these features generally involves reference to context, either the immediate co-textual environment, or to other texts or other corpora of texts (Thornbury, 2010, p. 271).

\subsection{Data}

For the purposes of this study, two corpora were used. The first was Mary Shelley's Frankenstein corpus generated by the Victorian Literary Studies Archive. This provides detailed information about the book's total word count and vocabulary distribution. Its web-based concordance offers a clear display and representation of the total number of text lines, the total word count and the number of occurrences of words and phrases. The second was the FRANKENSTEIN-COVID-19 Corpus. This corpus was compiled from 542 news articles and editorials from 83 newspapers. The rationale for building a corpus was that so far no corpus exists suitable for the purposes of the study. COVID-19 is still a new topic and many of the data have not yet been included in existing corpora. Furthermore, this study is not confined to a specific context; therefore, it is not appropriate to base it on the British National Corpus or the American National Corpus. Mary Shelley's Frankenstein is a universal novel, the ideas, concepts, and themes of which are still explored in literary and scientific circles all over the world. It is also the case that COVID-19 discourse is universal due to the nature of the pandemic, which is still afflicting the entire world. Thus, it was decided that the corpus should include texts from different countries, including the United Kingdom (UK), the United States (US), Canada, Australia, India, Pakistan, Italy, Ireland, France, and Germany.

The FRANKENSTEIN-COVID-19 corpus was developed to include only editorials and opinions written in English. Data were derived from different newspapers including The Independent, The Sun, The Mirror, The Guardian, News Letter, New York Times, The Washington Post, Sunday Guardian, Maclean's, The Times of India, Dawn, and The News (Pakistan). Data were collected between 1 March 2020 and 30 March 2021. The two key words Frankenstein and COVID-19 were used as data search terms. The data were randomly selected for objectivity purposes. Only texts including the two key terms were selected.

\subsection{Tools and Procedures}

Key Word in Context (KWIC) concordance was used to identify the recurrent patterns in both Mary Shelley's book and the FRANKENSTEIN-COVID-19 corpus. One advantage of the use of concordance analysis is that concordances can be employed usefully in determining the focus of texts through the identification of key words within the contexts in which they occur, referred to as KWIC (Biber \& Reppen, 2015). In the corpus of Mary Shelley's book, the three key words FRANKENSTEIN, MONSTER and CREATURE were first defined and their frequencies calculated. In discourse studies, frequency analysis can be used to determine the focus of texts (Meyer, 2002). Then, the recurrent patterns collocating the most with the three key terms were identified. Finally, generalizations about the recurrent themes in the novel and the representation of Gothic motifs were made.

In the same way, the two key words FRANKENSTEIN and COVID-19 in the FRANKENSTEINCOVID-19 corpus were searched and their frequencies were calculated. The recurrent themes 
associated with the two key words were identified and generalizations about these recurrent themes were made. Following the quantitative analysis of the data through the KWIC concordance and collocation analysis, qualitative analysis was carried out. Corpus contexts and language patterns were analysed qualitatively and described. In other words, the quantitative findings and information generated through concordance and collocation analysis will be used to support the qualitative statements and judgments about the corpus.

\section{Analysis}

In Frankenstein, Mary Shelley tells us about Victor Frankenstein, an ambitious scientist who succeeds in creating a monster, assembled from old body parts and strange chemicals. Unfortunately, the creature appears to be a dreadful and ugly beast in form and deed. In making this human being, Frankenstein feels guilty about violating the laws of nature and leaving him to suffer from the lack of having his basic needs met and being distressed by people's contempt. Victor runs away out of fear and disgust, after bringing this creature to life.

Frankenstein is a Gothic novel that focuses on strange and supernatural incidents taking place in an exotic, dark environment, thus causing readers considerable fear. The setting is an important element in a Gothic narrative. Evil spirits, ghosts or monsters are usually dreary, desolate, gloomy, abandoned, and haunted. Shelley draws on the Gothic setting so that the monster appears more looming, therefore arousing feelings of horror in the readers. The monster becomes more fearfully impressive when he appears in such a dark and gloomy Gothic setting, usually foregrounded by mystery and secrecy. Much of the action takes place at night and in mysterious circumstances. With the combination of the setting and circumstances, and the grotesque and macabre appearance of the monster, it is difficult - if not impossible - to understand the nature of the monster and what it is meant to be.

In quantitative terms, the monster FRANKENSTEIN is at the heart of the Gothic representation in the novel. Mary Shelley refers to it as the MONSTER or the CREATION. These two key words are repeated very frequently in the text. For the purposes of the study, the three key words CREATION, FRANKENSTEIN and MONSTER were selected. A frequency analysis of the three key words is shown in Table 1.

Table 1. Frequency list of the selected key words in Mary Shelley's Frankenstein

\begin{tabular}{ll}
\hline KEY WORD & FREQUENCY \\
\hline FRANKENSTEIN & 26 \\
MONSTER & 34 \\
CREATION & 19 \\
\hline
\end{tabular}

Using KWIC concordance analysis, the CREATION of FRANKENSTEIN the MONSTER appears to be associated with key concepts, including, death, crime, curiosity and discovery, darkness, fear, curses, dangers, murder, pain, ruin, solitude, and violence. These concepts are referred to as collocates, which have the function of providing useful insights into the meaning of the words close to which they occur. A frequency analysis of these collocates is shown in Table 2.

Table 2. Frequency list of the key concepts in Mary Shelley's Frankenstein

\begin{tabular}{ll}
\hline Collocates & Frequency \\
\hline Death & 79 \\
Discovery & 75 \\
Fear & 62 \\
\hline
\end{tabular}




\begin{tabular}{ll}
\hline Horror & 51 \\
Darkness & 44 \\
Crime & 29 \\
Grief & 28 \\
Pain & 24 \\
Destruction & 22 \\
Gloom & 21 \\
Curse & 18 \\
Dangers & 17 \\
Solitude & 15 \\
Curiosity & 14 \\
Violence & 10 \\
Threat & 9 \\
\hline
\end{tabular}

The analysis of the quantitative data indicates the centrality of Gothic motifs in Mary Shelley's Frankenstein, as already identified in the focus on the prevalent attributes, circumstances, and contexts related to Gothic settings outlined above - the isolation of characters in the dark and the horror of the monsters abroad. Gothic settings are then exploited to represent the fears and horrors imposed on humanity with the creation of the monster Frankenstein.

As a next step, KWIC was used to explore the FRANKENSTEIN-COVID-19 Corpus. Using Conc, a software program developed by SIL Language Technology, which produced KWIC, it was clear that the three terms FRANKENSTEIN, COVID-19, and MONSTER VIRUS were the most frequent in the corpus, as shown in Table 3. These were therefore selected as the key words for the analysis.

Table 3. Frequency list of the key words selected in the FRANKENSTEIN-COVID-19 Corpus

\begin{tabular}{ll}
\hline KEY WORDS & FREQUENC \\
& $\mathrm{Y}$ \\
\hline FRANKENSTEIN & 748 \\
COVID-19 & 921 \\
MONSTER & 589 \\
VIRUS & \\
\hline
\end{tabular}

The three key terms COVID-19, FRANKENSTEIN and MONSTER VIRUS collocate with different words, including plague, horror, fear and death. The frequencies of these collocates with each of the three key terms COVID-19, FRANKENSTEIN and MONSTER VIRUS are shown in Table 4.

Table 4. Frequency analysis of collocates with the KEY WORDS in the FRANKENSTEIN-COVID-19 Corpus

\begin{tabular}{lcccc}
\hline Term & COVID-19 & FRANKENSTEIN & $\begin{array}{c}\text { MONSTER } \\
\text { VIRUS }\end{array}$ & Frequency \\
\hline China & 148 & 148 & 129 & 425 \\
Horror & 143 & 143 & 86 & 372 \\
Wuhan & 129 & 129 & 111 & 369 \\
Death & 123 & 123 & 89 & 335 \\
Fear & 129 & 129 & 74 & 332 \\
Chinese & 117 & 117 & 58 & 292 \\
Gloomy & 98 & 98 & 75 & 271 \\
Solitude & 84 & 84 & 64 & 232 \\
Lockdown & 88 & 88 & 52 & 228 \\
\hline
\end{tabular}




\begin{tabular}{lllll}
\hline Gothic & 79 & 79 & 66 & 224 \\
Ravage & 89 & 89 & 35 & 213 \\
Terror & 94 & 94 & 16 & 204 \\
Dread & 83 & 83 & 28 & 194 \\
Darkness & 78 & 78 & 23 & 179 \\
Laboratories & 67 & 67 & 39 & 173 \\
Discovery & 67 & 67 & 34 & 168 \\
Technology & 58 & 58 & 46 & 162 \\
Closed & 64 & 64 & 28 & 156 \\
Threat & 61 & 61 & 29 & 151 \\
Curiosity & 59 & 59 & 32 & 150 \\
Shadows & 67 & 67 & 11 & 145 \\
Crime & 56 & 56 & 19 & 131 \\
Destruction & 48 & 48 & 27 & 123 \\
Quarantine & 52 & 52 & 17 & 121 \\
Curse & 47 & 47 & 18 & 112 \\
Masks & 45 & 45 & 17 & 107 \\
Pain & 35 & 35 & 17 & 87 \\
Grief & 33 & 33 & 12 & 78 \\
Dangers & 23 & 23 & 16 & 62 \\
\hline
\end{tabular}

Based on the frequency distribution of these lexical patterns, it is clear that they represent distinct groups used to reveal and map the thematic structure and representation of the selected discourses, as shown in Figure 1.

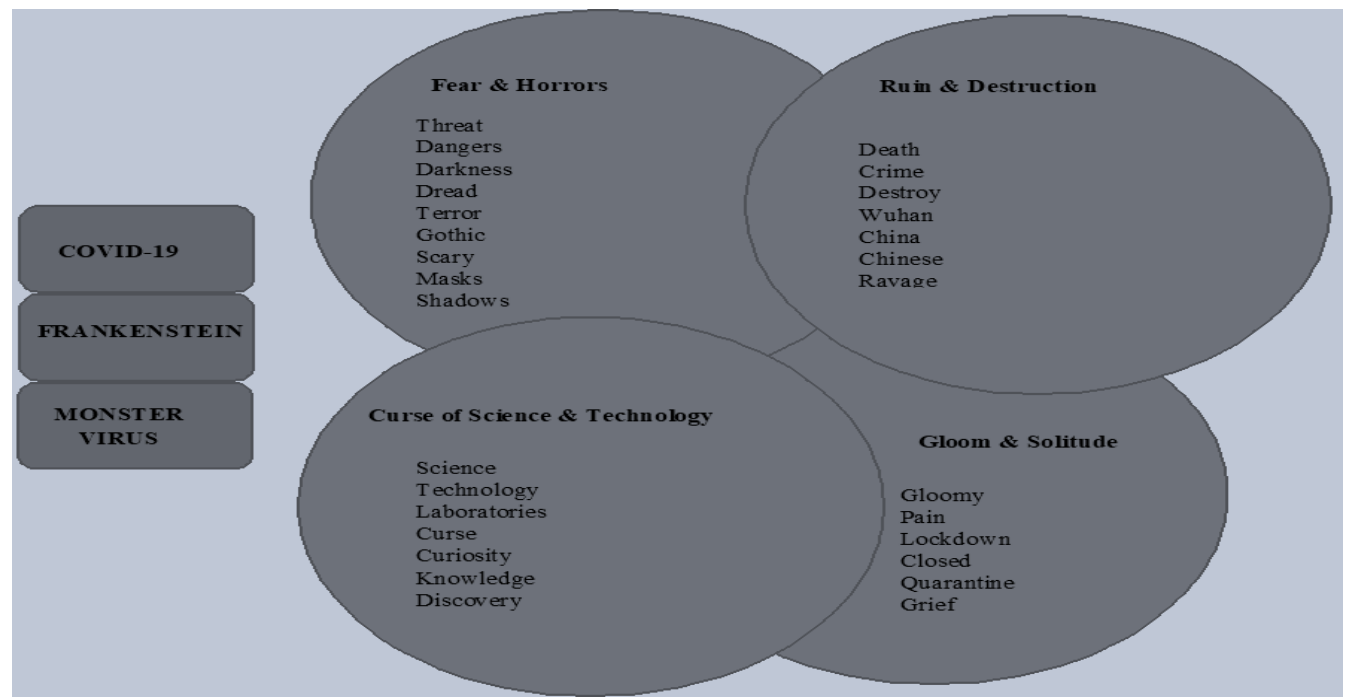

Figure 1. Thematic mapping of the FRANKENSTEIN-COVID-19 Corpus based on the lexical patterns

\section{Discussion}

The findings indicate that there is a correspondence between the key themes in both Mary Shelley's book and the FRANKENSTEIN-COVID-19 Corpus. This significant correlation between the fictional Gothic world of Mary Shelley and what can be referred to as the COVID-Frankenstein journalistic discourse is established through the lexical patterns in the two corpora. In the selected COVID-19 texts, the representation of the virus is constructed as a destructive force which has become impossible 
to control. In the corpus, it "is every bit as scary as Mary Shelley's creation". Fear and horror are everywhere. People's lives are threatened and indeed plagued. Disasters and failures surround humanity. Cities of the world are described as "shadows". The lockdown procedures imposed by governments due to the COVID-19 pandemic have had negative impacts on social life, with restrictions placed on social activities in almost all countries. People have also not been allowed to move from one place to another. In this context, people have lived in isolation. They have also been surrounded by fears due to the increasing coronavirus death rates: “...the smell of death is in every corner".

In literary terms, the Gothic elements are manifested in the COVID-19 journalistic discourse based on the image of Frankenstein. The Gothic tradition is based on key elements and motifs, including the setting, horrors, fears, gloom, terror, darkness, and death (Geary, 1992; Graham, 1999; Snodgrass, 2014). These elements are all found in the FRANKENSTEIN-COVID-19 Corpus. It can thus be claimed that the journalistic accounts of the pandemic constitute Gothic representations of the event through the focus on concepts of chaos, contagion, curse, darkness, death, destruction, disaster, failure, fear, horrors, isolation, plague, ruin, and solitude. The mainstream representations of the COVID-19 discourse comprise chaos, fear, destruction, gloom, horror, and death. This entails that the Gothic motifs represented in the COVID-19 journalistic discourse are in many ways a reproduction of those in Mary Shelley's Frankenstein.

Many journalists and writers have related the virus to China, which for them represents Victor Frankenstein. Indeed, many writers have tried to promote the idea that the virus was created in a secret laboratory in China. This argument was supported by then President Trump himself, who described COVID-19 as the Chinese virus, among other epithets linked to the country. The Chinese government was represented as Victor Frankenstein in not sharing information rapidly and transparently. Many writers accused the Chinese of being good at keeping secrets and journalistic reports highlighted the accusations of Chinese officials being untruthful and less than forthcoming in reporting accurate data on the death march caused by the virus. Other opinions linked the virus to capitalistic forces in favour or money and dominance, represented as Victor Frankenstein in the desire for immortality. Victor Frankenstein wanted to conquer death, but instead created a creature that he himself hated and despised. In the same way, the capitalist forces were accused of creating a virus to control people.

In Frankenstein, Mary Shelley manipulates the Gothic elements to reflect on the effects of the technological invasion of modern life and the use of knowledge for evil purposes. She implies that the Industrial Revolution defaced the restorative power of nature, spreading poverty, ugliness, social transgressions, scepticism and the loss of faith, and crime and evil everywhere. Through the monster creation of Frankenstein, she warned against the deterioration of morals, as well as the danger of excessive knowledge, which ultimately becomes a curse. In the same way, the COVID-19 discourses raised questions about trust in science and technology, and the link between science and religion.

Parallels can also be drawn between Victor's ugly creation and COVID-19, the latter being referred to as the "new Frankenstein monster virus" that "is now ravaging the world" and bringing it "down to its knees". Just like Frankenstein's monster, the monster virus is mysterious. There is no consensus concerning the nature of the virus so far. The use of the double is also a significant Gothic motif in both Mary Shelley's book and COVID-19 journalistic discourse. The monster chases Victor wherever he goes. In the same way, the virus chases people wherever they go. There is no secure place. The entire world is afflicted.

Based on the above analysis, it is apparent that the Gothic motifs in Mary Shelley's Frankenstein lend themselves to a representation in the COVID-19 journalistic discourse that illustrates the calamity that has befallen the world and in itself comprises a particular and discrete genre. 


\section{Conclusions}

This study addressed the issue of the thematic representation of the COVID-19 journalistic discourse based on Mary Shelley's fictional image of Frankenstein. A corpus of 542 news articles and editorials from 83 newspapers was compiled. The thematic representation of the corpus was explored in light of Mary Shelley's Frankenstein. The findings indicate that there is a correspondence between the key themes in Mary Shelley's book and the FRANKENSTEIN-COVID-19 Corpus. This significant correlation between the fictional Gothic world of Mary Shelley and what can be referred to as the COVID-Frankenstein journalistic discourse is established through a close association between COVID-19 and the Gothic motifs of Frankenstein. These Gothic motifs have been manipulated to highlight the conceptions of fear, horrors, terror, ruin, gloom, and death which emerged with the outbreak of the monster virus. It can be concluded that the COVID-19 journalistic discourse based on the fictional image of Frankenstein and his monster represents a distinct discourse genre that manipulates Gothic motifs in the thematic representations of the horrors associated with the pandemic on the one hand and the social, economic, and political problems and crises that have shaken the stability of the entire world on the other. The representation of the Gothic motifs in the COVID-19 journalistic discourse is generated and developed from the interaction between the writers and Mary Shelley's Frankenstein.

\section{Acknowledgement}

The corresponding author would like to acknowledge the support provided by the Deanship of Scientific Research (DSR) at King Abdulaziz University, Jeddah, Saudi Arabia.

\section{References}

Allan, R., \& Buijs, M. (2007). The language of literature: Linguistic approaches to classical texts. Leiden: Brill.

Baker, P. (2006). Using corpora in discourse analysis. London: Continuum.

Baker, P. (2012). Contemporary corpus linguistics. London: Continuum International Publishing.

Baker, P., \& McEnery, T. (2015). Corpora and discourse studies: Integrating discourse and corpora. London: Palgrave Macmillan UK.

Biber, D., \& Reppen, R. (2015). The Cambridge handbook of English corpus linguistics. Cambridge: Cambridge University Press.

Buckley, C. A. G. (2016). Nomadic intertextuality and postmillennial children's Gothic fiction (Unpublished doctoral thesis). Lancaster University, Lancaster.

Buzwell, G. (2014). Mary Shelley, Frankenstein and the Villa Diodati Discovering Literature: Romantics \& Victorians, Romanticism, The Gothic, The novel 1780-1832. Retrieved from https://www.bl.uk/romantics-and-victorians/articles/mary-shelley-frankenstein-and-the-villadiodati\#

Corstorphine, K., \& Kremmel, L. R. (2018). The Palgrave handbook to horror literature. New York: Springer International Publishing.

Dunne, M. (2001). Intertextual encounters in American fiction, film, and popular culture. Bowling Green, OH: Bowling Green State University Popular Press. 
Edmundson, M. (2016). The Gothic tradition in Supernatural: Essays on the television series. Jefferson, NC: McFarland \& Company.

Foucault, M. (1990). The history of sexuality: An introduction. London: Vintage Books.

Garrett, P. (2018). Gothic reflections: Narrative force in nineteenth-century fiction. Ithaca, NY: Cornell University Press.

Geary, R. F. (1992). The Supernatural in Gothic fiction: Horror, belief, and literary change. Lewiston, NY: Edwin Mellen Press.

Graham, W. C. (1999). Gothic elements and religion in Nathaniel Hawthorne's fiction: TectumVerlag.

Grundmann, A. (2007). Intertextuality in Ken Russel's "Gothic": The representation of the Romantic Period and the motif of the artificial being. München, Germany: GRIN Verlag.

Hermansson, C. (2001). Reading feminist intertextuality through Bluebeard stories. New York: Edwin Mellen Press.

Hogle, E. J. (2002). The Cambridge companion to Gothic fiction. Cambridge: Cambridge University Press.

Howard, J. (1994). Reading Gothic fiction: A Bakhtinian approach. Oxford: Clarendon Press.

Jakobson, R. (1960). Closing statement: Linguistics and poetics. In T. Sebeok (Ed.), Style in language (pp. 351-449). Cambridge, MA: Massachusetts Institute of Technology.

Johnson, B., Butler, J., \& Felman, S. (2014). A Life with Mary Shelley. Redwood City, CA: Stanford University Press.

Kennedy, G. (2014). An introduction to corpus linguistics. London; New York: Routledge.

Louw, B., \& Milojkovic, M. (2016). Corpus stylistics as contextual prosodic theory and subtext. Amsterdam: John Benjamins.

McCarthy, M., \& O'Keeffe, A. (2010). Historical perspective: What are corpora and how have they evolved? In A. O'Keeffe \& M. McCarthy (Eds.), The Routledge handbook of corpus linguistics (pp. 3-13). London; New York: Routledge.

McEnery, T., \& Hardie, A. (2011). Corpus linguistics: Method, theory and practice. Cambridge University Press.

Mellor, A. K. (1988). Mary Shelley, her life, her fiction, her monsters. North Yorkshire: Methuen.

Meyer, C. F. (2002). English corpus linguistics: An introduction. Cambridge: Cambridge University Press.

Michelis, A. (2003). "Dirty Mamma": Horror, vampires, and the maternal in late nineteenth-century Gothic fiction. Critical Survey, 15(3), 5-22

Mulvey-Roberts, M. (1998). The handbook to Gothic literature. New York: New York University Press.

Peck, H. T. (1897). Harper's dictionary of classical literature and antiquities. New York: Harper.

Peer, W., Hakemulder, F., \& Zyngier, S. (2012). Scientific methods for the humanities. Amsterdam: John Benjamins. 
Punter, D. (2014). The literature of terror: Volume 1: The Gothic tradition. London; New York: Routledge.

Punter, D. (2015). A new companion to the Gothic. Hoboken, NJ: Wiley.

Raškauskienè, A. (2009). Gothic fiction: The beginnings. Kaunas: Vytauto Didžiojo Universitetas (VDU) Press.

Salama, A. (2021). A methodological synergy of dramatistic discourse analysis and corpus linguistics: From the discourse of US Presidents to Trump's 2016 Orlando speech. Journal of Language and Linguistic Studies, 17(Special Issue 2), 752-772

Sampson, F. (2019). In search of Mary Shelley. xx: Pegasus Books.

Shelley, M. (1869). Frankenstein: Or, the modern Prometheus. Cambridge: Sever Francis \& Co.

Snodgrass, M. E. (2014). Encyclopedia of Gothic literature. New York: Facts on File, Incorporated.

Thornbury, S. (2010). What can a corpus tell us about discourse? In A. O'Keeffe \& M. McCarthy (Eds.), The Routledge handbook of corpus linguistics (pp. 270-287). London; New York: Routledge.

Ustabulut, M. Y., \& Keskin, S. (2020). 'Tele-education' in the COVID-19 pandemic process in Turkey: A mental diaspora research specific to Turkish Language Teaching students. Journal of Language and Linguistic Studies, 16(4), 2163-2182.

Walpole, H. (1764). The Castle of Otranto. London: Penguin.

Walpole, H. (1982). Preface to The Castle of Otranto. Oxford: Oxford University Press.

Wisker, G. (2016). Contemporary women's Gothic fiction: Carnival, hauntings and vampire kisses. London: Palgrave Macmillan UK.

Wright, A. (2007). Gothic fiction. London: Palgrave Macmillan.

\section{AUTHOR BIODATA}

Fahad M. Alliheibi is a Full Professor of Arabic Language and Linguistics in the Department of Arabic Language, Faculty of Arts, King Abdulaziz University (KAU), Jeddah, Saudi Arabia. Prof. Alliheibi received his $\mathrm{PhD}$ degree in Linguistics in 1999 from Durham University, UK. His research interests include Arabic Linguistics, Pragmatics, Text Linguistics, and Translation.

Abdulfattah Omar is an Associate Professor of English Language and Linguistics in the Department of English, College of Science \& Humanities, Prince Sattam Bin Abdulaziz University (KSA). Also, he is a standing lecturer of English Language and Linguistics in the Department of English, Faculty of Arts, Port Said University, Egypt. Dr Omar received his PhD degree in computational linguistics in 2010 from Newcastle University, UK. His research interests include computational linguistics, digital humanities, discourse analysis, and translation studies.

Nasser Al-Horais is a Full Professor of Arabic Language and Linguistics in the Department of Arabic Language and its Arts, College of Arabic Language \& Social Studies, Qassim University (KSA). Prof. Al-Horais received his $\mathrm{PhD}$ degree in Linguistics in 2009 from Newcastle University, UK. His research interests include Arabic Syntax, Generative Linguistics (Minimalist Program), Discourse Analysis, and Comparative Syntax. 